\title{
Pengaruh Kecerdasan Spiritual dan Profesionalisme Auditor Internal terhadap Pencegahan Kecurangan \\ (Survei pada Auditor Internal BUMN di Kota Bandung)
}

\section{Determinants of Internal Auditor's Spirititual Quotient and Professionalism on Fraud Prevention (Survey on Internal Auditors of SOEs in Bandung City)}

\author{
${ }^{1}$ Fikri Abdul Malik, ${ }^{2}$ Pupung Purnamasari, ${ }^{3}$ Mey Maemunah \\ ${ }^{1,2,3}$ Prodi Akuntansi, Fakultas Ekonomi dan Bisnis, Universitas Islam Bandung, \\ Jl. Tamansari No.1 Bandung 40116 \\ email: ${ }^{1}$ fikriabdulmalik96@gmail.com, ${ }^{2}$ __purnamasari@yahoo.co.id, ${ }^{3}$ mey_maemunah@yahoo.com
}

\begin{abstract}
This study aims to determine the effect of spirititual quotient and professionalism of internal auditors on fraud prevention. This study used a sample of 63 respondents on internal auditors of SOEs in Bandung city. The type of data used is primary data, that is collected by distributing questionnaires to each company. This research uses descriptive and verification methods. The hypothesis testing is done by multiple regression analysis with SPSS 22 as statistical tool. The results showed that the spirititual quotient and professionalism of internal auditors influence the prevention of fraud. The next research is suggested to increase the number of respondents, so the research result will be more generalizable. There are various other variables that can be added to make more interesting discussion.
\end{abstract}

\section{Keywords: Spirititual Quotient, Professionalism of Internal Auditors, Fraud} Prevention.

Abstrak. Penelitian ini bertujuan untuk mengetahui pengaruh kecerdasan spiritual dan profesionalisme auditor internal terhadap pencegahan kecurangan. Penelitian ini menggunakan sampel sebanyak 63 responden auditor Internal BUMN di Kota Bandung. Jenis data yang digunakan adalah data primer, yaitu dengan cara menyebarkan kuesioner kepada setiap perusahaan. Metode penelitian ini menggunakan metode deskriptif dan verifikatif, serta pengujian hipotesis dilakukan dengan pengujian regresi berganda menggunakan software SPSS 22. Hasil penelitian menunjukan bahwa kecerdasan spiritual dan profesionalisme auditor internal berpengaruh terhadap pencegahan kecurangan. Saran bagi penelitian selanjutnya untuk menambahkan jumlah responden, sehingga hasil penelitian dapat digeneralisasi lebih luas. Penulis menyarankan untuk menambah variabel lain agar penelitian lebih menarik untuk dibahas.

Kata Kunci: Kecerdasan Spiritual, Profesionalisme Auditor Internal, Pencegahan Kecurangan.

\section{A. Pendahuluan}

Badan Usaha Milik Negara (BUMN) mempunyai peranan penting dalam penyelenggaraan perekonomian nasional guna mewujudkan kesejahteraan masyarakat. Peran yang dimiliki oleh BUMN ini menjadikan perusahaan tersebut harus bersaing dengan perusahaan-perusahaan yang menjadi milik perseorangan atau perseroan lainnya. Persaingan yang terjadi pada akhirnya menuntut setiap orang yang ada pada 

perusahaan, termasuk BUMN untuk memperlihatkan kinerja yang optimal. Namun demikian, fakta di lapangan BUMN masih banyak yang mengalami kerugian dengan ini menunjukkan bahwa kecurangan sering terjadi.

Kerugian-kerugian BUMN pada tahun 2016 mencapai 6.7 triliun yang terdiri dari 26 BUMN, kemudian pada tahun 2017 berikutnya kerugian menurun menjadi sebesar 5.2 triliun yang terdiri dari 12 BUMN (www.detik.com). Mirisnya di sisi lain kerugiankerugian yang dialami oleh beberapa BUMN ini bersal dari penyimpangan keuangan. Penelaahan Badan Administrasi Kepegawaian Negara terhadap pemeriksaan KPK semester I periode 2013 sedikitnya menemukan 510 kasus penyimpangan keuangan negara, antara lain sebanyak 234 kasus terkait kelemahan Sistem Pengendalian Internal (SPI), dan 276 kasus terkait ketidakpatuhan terhadap ketentuan perundang-undangan.

Ketidak patuhan kepada ketentuan yang ada merupakan pelanggaran etika, padahal pertimbangan etika sangatlah penting bagi status profesional dalam menjalankan aktivitasnya. Etika profesi merupakan faktor organisasional yang akan mempengaruhi kinerja seorang auditor. Ada beberapa elemen penting yang harus dimiliki oleh auditor, yaitu keahlian dan pemahaman tentang standar akuntansi atau standar penyusunan laporan keuangan, standar pemeriksaan atau auditing, etika profesi dan pemahaman terhadap lingkungan bisnis yang diaudit. Sehingga syarat utama yang harus dimiliki oleh seorang auditor adalah wajib memegang teguh aturan etika profesi yang berlaku. Maka dari itu, etika profesi merupakan sarana pengaturan diri yang sangat menentukan bagi pelaksanaan profesi sebagaimana diharapkan oleh masyarakat. Seorang auditor selain wajib memegang teguh aturan etika profesi yang berlaku, di dalam dunia bekerja hingga menentukan dalam pencegahan kecurangan, seorang auditor juga dituntut untuk menggunakan kecerdasan spiritualnya.

Selain kecerdasaan spiritual ada faktor lain yang mempengaruhi pencegahan kecurangan yaitu profesionalisme. Menurut Arens et al (2010:108) profesionalisme adalah tanggung jawab untuk bertindak lebih dari sekedar memenuhi tanggung jawab untuk bertindak lebih dari sekedar memenuhi tanggung jawab diri sendiri maupun ketentuan hukum dan peraturan masyarakat. Sedangkan menurut Tugiman (2011:27) profesionalisme merupakan tanggung jawab bagian audit internal dan setiap auditor internal. Pimpinan audit internal dalam setiap pemeriksaan harus menugaskan orangorang yang secara bersamaan atau keseluruhan memiliki pengetahuan, kemampuan dan berbagai disiplin ilmu yang diperlukan untuk melaksanakan pemeriksaan secara tepat dan pantas. Hasil penelitian yang diteliti Widaningsih dan Hakim (2015) dengan hasil analisis menunjukan bahwa profesionalisme auditior internal terdapat pengaruh positif yang signifikan terhadap upaya pencegahan kecurangan (fraud).

Berdasarkan latar belakang yang telah diuraikan, maka penelitian ini hendak menguji secara empiris apakah terdapat pengaruh kecerdasan spiritual dan profesionalisme auditor internal terhadap pencegahan kecurangan.

\section{B. Landasan Teori}

Menurut Amin (2008:2) Internal audit sebagai kegiatan asurance dan konsultasi yang independen dan obyektif, yang dirancang untuk memberikan nilai tambah dan meningkatkan kegiatan operasi organisasi. Audit internal membantu organisasi untuk mencapai tujuannya, melalui suatu pendekatan yang sistematis dan teratur untuk mengevaluasi dan meningkatkan efektivitas pengelolaan risiko, pengendalian, dan proses governance. 

Auditor internal adalah suatu aktivitas yang independen, objektif, memberikan jaminan dan konsultasi yang dibuat untuk memberikan nilai serta meningkatkan operasi suatu organisasi. Auditor internal membantu suatu organisasi untuk mencapai tujuannya dengan membawa pendekatan yang sistematis dan disiplin untuk mengevaluasi dan meningkatkan keefektifan sistem informasi akuntansi.

Menurut Danah Zohar dan Ian Marshall (2002) kecerdasan spiritual adalah kecerdasan untuk menghadapi dan memecahkan persoalan makna dan nilai, yaitu menempatkan perilaku dan hidup manusia dalam konteks makna yang lebih luas dan kaya, serta menilai bahwa tindakan atau jalan hidup seseorang lebih bermakna dibandingkan dengan yang lain.

Pengertian profesionalisme yang dikemukakan oleh Arens et al (2010:108) menyatakan bahwa profesionalisme adalah tanggun jawab untuk bertindak lebih dari sekdar memenuhi tanggung jawab diri sendiri maupun ketentuan hukum dan peraturan yang ada di dalam masyarakat.

\section{Metode Penelitian}

Metode penelitian yang digunakan dalam penelitian ini adalah metode deskriptif verifikatif. Sampel yang digunakan dalam penelitian ini adalah 63 responden auditor Internal BUMN di Kota Bandung. Pengujian hipotesis yang dilakukan adalah dengan menggunakan regresi beganda dengan software SPSS 21.

\section{Hasil Penelitian dan Pembahasan}

Pada penelitian ini, teknik analisis data yang digunakan untuk pengujian hipotesis dalam penelitian ini adalah analisis regresi linear berganda. Berikut merupakan hasil penelitian mengenai pengaruh kecerdasan spiritual dan profesionalisme auditor internal terhadap pencegahan kecurangan yang akan dijelaskan pada tabel berikut:

\begin{tabular}{|c|c|c|c|c|c|c|}
\hline & & \multicolumn{5}{|c|}{ Coefficients $^{\mathrm{a}}$} \\
\hline & \multirow{2}{*}{ Model } & \multicolumn{2}{|c|}{$\begin{array}{c}\text { Unstandardized } \\
\text { Coefficients }\end{array}$} & $\begin{array}{l}\text { Standardized } \\
\text { Coefficients }\end{array}$ & \multirow[b]{2}{*}{$\mathrm{T}$} & \multirow[b]{2}{*}{ Sig. } \\
\hline & & $\mathrm{B}$ & Std. Error & Beta & & \\
\hline \multirow[t]{3}{*}{1} & (Constant) & 12.684 & 4.115 & & 3.083 & .003 \\
\hline & Kecerdasan Spiritual & 0.148 & 0.127 & 0.139 & 2.158 & .025 \\
\hline & $\begin{array}{l}\text { Profesionalisme } \\
\text { auditor }\end{array}$ & 0.664 & 0.126 & 0.632 & 5.268 & .000 \\
\hline
\end{tabular}

a. Dependent Variable: Pencegahan Kecurangan

Sumber: Hasil Pengolahan SPSS versi 22, 2018

\section{Pengaruh Kecerdasan Spiritual terhadap Pencegahan Kecurangan}

Hasil uji analisa berganda diperoleh nilai signifikansi kecerdasan spiritual sebesar 0.025 lebih kecil dari nilai alpha $\alpha=0.05$. Hal tersebut dapat disimpulkan bahwa secara statistik kecerdasan spiritual mempunyai pengaruh terhadap pencegahan kecurangan. Bila kinerja auditor tersebut baik maka hasil yang diberikan pun akan baik pula. Kecerdasan spiritual mengajarkan orang untuk mengekspresikan dan memberi makna pada setiap tindakannya, dengan demikian dapat disimpulkan bahwa untuk mencegah terjadinya kecurangan diperlukan jiwa spiritual yang baik. Dengan demikian hasil penelitian ini dapat disimpulkan bahwa kecerdasan spiritual sangat penting bagi 

seorang auditor internal guna menghasilkan hasil yang baik dan mencegah terjadinya kecurangan.

Menurut Zohar dan Marshall (2002) kecerdasan spiritual adalah kecerdasan untuk menghadapi dan memecahkan persoalan makna dan nilai, yaitu menempatkan perilaku dan hidup manusia dalam konteks makna yang lebih luas dan kaya, serta menilai bahwa tindakan atau jalan hidup seseorang lebih bermakna dibandingkan dengan yang lain. Dimana kemampuan manusia memaknai bagaimana arti dari kehidupan serta memahami nilai tersebut dari setiap perbuatan yang dilakukan dan kemampuan potensial setiap manusia yang menjadikan seseorang dapat menyadari dan menentukan makna, nilai, moral, serta cinta terhadap kekuatan yang lebih besar dan sesama makhluk hidup karena merasa sebagai bagian dari keseluruhan, sehingga membuat manusia dapat menempatkan diri dan hidup lebih positif dengan penuh kebijaksanaan, kedamaian, dan kebahagiaan yang hakiki (Zakiah, 2013). Tanpa adanya kematangan kecerdasan spiritual sangat sulit bagi seorang auditor memikul tanggung jawab seperti apa yang disebutkan dalam Pedoman Kode Etik Akuntan Indonesia, serta untuk tidak menyalahgunakan kemampuan dan keahlian yang merupakan amanah yang dimilikinya kepada jalan yang tidak dibenarkan.

\section{Pengaruh Profesionalisme Internal Auditor terhadap Pencegahan Kecurangan}

Hasil uji analisa berganda diperoleh nilai signifikansi kepemilikan saham eksekutif sebesar 0.000 lebih kecil dari nilai alpha $\alpha=0.05$. Hal tersebut dapat disimpulkan bahwa secara statistik profesionalisme auditor internal mempunyai pengaruh terhadap pencegahan kecurangan. Dengan demikian hasil penelitian ini menemukan bahwa profesionalisme auditor berpengaruh terhadap pencegahan kecurangan.

Menurut Tugiman (2011:119) menyatakan bahwa profesionalisme merupakan suatu sikap dan perilaku seseorang dalam melakukan profesi tertentu. Sehingga dengan adanya profesionalisme auditor internal mempunyai rasa tanggungjawab dan ketaatan pada peraturan hukum. Oleh sebab itu, profesionalisme auditor internal memungkinkan untuk melakukan pencegahan kecurangan. Semakin tinggi profesionalisme auditor internal maka akan semakin tinggi pula intensi dalam melakukan pencegahan kecurangan.

Hasil pengujian ini menggambarkan bahwa internal auditor yang memiliki profesionalisme yang tinggi akan meningkatkan pencegahan terhadap kecurangan. Auditor internal yang membuat keputusan auditnya, dapat merencanakan dan memutuskan hasil auditnya, serta tidak adanya intervensi dengan pihak lain, makan akan meningkatkan niat untuk melakukan pencegahan atau bahkan akan mengungkapkan adanya kecurangan. Dengan adanya independensi dari internal akan menimbulkan keberanian untuk mengungkapkan adanya pelanggaran (Yusar Sugara, 2013).

Hasil penelitian ini sesuai dengan hasil penelitian yang dilakukan oleh Mimin dan Desy (2015) yang menyataan bahwa terdapat pengaruh yang signifikan antara profesionalisme auditor internal terhadap upaya pencegahan kecurangan (fraud). 



\section{Pengaruh Kecerdasan Spiritual dan Profesionalisme Internal Auditor terhadap Pencegahan Kecurangan}

Hasil pengujian kecerdasan spiritual terhadap pencegahan kecurangan mempunyai nilai $0.025<0,05$. Hal ini menunjukan bahwa kecerdasan spiritual memiliki pengaruh terhadap pencegahan kecurangan.

Hasil pengujian profesionalisme internal auditor terhadap pencegahan kecurangan mempunyai nilai $0,000<0,05$. Hal ini menunjukan bahwa profesionalisme auditor internal memiliki pengaruh terhadap pencegahan kecurangan.

\section{E. Kesimpulan dan Saran \\ Kesimpulan}

Berdasarkan pembahasan, beberapa hasil penelitian yang dapat disimpulkan adalah sebagai berikut:

1. Kecerdasan spiritual berpengaruh terhadap pencegahan kecurangan

2. Profesionalisme auditor internal berpengaruh terhadap pencegahan kecurangan

\section{Saran}

1. Saran untuk perusahaan yaitu meningkatkan mutu kepribadian diri karyawan agar terciptanya standar perilaku yang dipatuhi oleh karyawan serta untuk meningkatkan tanggung jawab karyawan dalam menjalankan tugas yang diberikan perusahaan .

2. Saran bagi peneliti sebelumnya, penelitian selanjutnya disarankan untuk menambah jumlah responden sehingga hasil penelitian ini dapat digeneralisasi lebih luas.

\section{F. Daftar Pustaka}

Amin, Widjaja Tunggal. 2008 . Audit Manajemen. Jakarta : Rineka Cipta

Arens, Alvin A. et.al. 2010. Auditing and Assurance Services: An Integrated Approach Thirteenth Edition. New Jersey: Pearson Prentice Hall.

Arens, Alvin A., Elder, dan Beasly. 2008. Auditing dan Jasa Assurance Pendekatan Terintegrasi Jilid I. Edisi 12. Jakarta : Erlangga.

Badan Pengawasan Keuangan Dan Pembangunan. (2008). Fraud Auditing. Edisi kelima. Bogor: Pusdiklatwas BPKP.

Badan Pengawasan Keuangan dan Pembangunan. (2011). Audit Internal Harus Siap Untuk Selalu Berada di Depan Menjadi Mitra yang Profesional. [Online].

diakses dari : http://www.bpkp.go.id/dan/berita/read/7275/30/auditor-internalharus siap-untuk-selalu-berada-di-depan-dan-menjadi-mitra-yang profesional.bpkp

Fariah, Zakiah. 2013. Jurnal Kecerdasan Emosional dan Kecerdasan spiritualTerhadap Kinerja Auditor, 2009.

Fitrawansyah. 2014. Fraud \& Auditing. Jakarta : Mitra Wacana Media

Mimin,Widianingsih. \& Desy . Nur . Hakim .2015. Pengaruh ProfesionalismeAuditor Internal Terhadap Pencegahan Dan Pendeteksian Kecurangan. $\quad$ (survey bumn yang ada di kota bandung). (skripsi). Uiversitas Pendidikan Indonesia .

Tugiman, Hiro. 2011. Standar Profesi Audit Internal. Edisi Tujuh. Yogyakarta: Kanisius.

www.detik.com 

Zohar, Danah dan Marshall. 2002. SQ. Memanfaatkan Kecerdasan Spiritual Dalam Berpikir Integralistik dan Holistik untuk Memaknai Kehidupan. (R.Astuti, Trans.) Bandung: PT Mizan Media Utama. 